\title{
The Gift of Necessity, A Case Study of Lecturers' Use of Webinars
}

\author{
Mani Festati Broto ${ }^{1}$, and Widyasari ${ }^{2}$ \\ ${ }^{1}$ Universitas Terbuka, Tangerang Selatan, Banten, Indonesia \\ e-mail:mani@ecampus.ut.ac.id
}

\begin{tabular}{|c|c|}
\hline Article Info & Abstract \\
\hline $\begin{array}{l}\text { Article history: } \\
\text { Received } \\
\text { May } 12^{\text {th }}, 2021 \\
\text { Revised } \\
\text { July } 19^{\text {th }}, 2021 \\
\text { Accepted } \\
\text { July } 26^{\text {th }}, 2021 \\
\text { Published } \\
\text { July } 30^{\text {th }}, 2021\end{array}$ & $\begin{array}{l}\text { This started as a brief and simple survey aimed to measure the extent to which } \\
\text { university lecturers were compelled to attend webinars after the WfH policy was in } \\
\text { place, in terms of motivation, challenges and benefits of webinar attendance. The } \\
\text { survey also tried to see how instructors would one of their duties under the Univer- } \\
\text { sity Instructors' Three Pillars of Higher Education comprising Education, Research } \\
\text { and Community Service. It applies the descriptive qualitative approach to identi- } \\
\text { fying how they understand the aspect of social interaction. This study focuses on } \\
\text { how instructors make use of webinar technology out of necessity that later proved, } \\
\text { time-wise, to be more effective and efficient in organization. 'Time' can be managed } \\
\text { in the most efficient way possible, and turns out to be a gift, in that it facilitates the } \\
\text { enhancement of knowledge. However, webinars still cannot be substitutes for the } \\
\text { sorely-missed social interactions. }\end{array}$ \\
\hline
\end{tabular}

Keywords: information and communications technology; webinar; work from home

\begin{tabular}{l}
\hline Abstrak \\
\hline Tulisan ini berawal dari survei singkat dan sederhana untuk mengetahui se- \\
jauh mana keterpaksaan dosen mengikuti webinar setelah pembelakukan WfH, \\
dari aspek motivasi, kendala dan manfaat mengikuti webinar. Bagaimana dosen \\
melaksanakan salah satu tugas Tridharma Dosen yaitu seminar secara online \\
(webinar). Pendekatan kualitatif deskriptif digunakan untuk mengetahui pemak- \\
naan dari aspek interaksi sosial. Pembahasannya mengarah bahwa pemanfaatan \\
teknologi webinar dosen dari situasi keterdesakan, yang kemudian dari 'waktu' \\
ternyata lebih efektif dan efisien dalam pengaturannya. Aspek 'waktu' dapat di- \\
manfaatkan se-efektif dan pada kenyataannya memberi anugerah penambahan \\
ilmu pengetahuan. Namun demikian, webinar belum dapat menggantikan kerin- \\
duan untuk interaksi sosial.
\end{tabular}

Kata Kunci: teknologi informasi dan komunikasi; webinar; bekerja dari rumah 


\section{INTRODUCTION}

The digital transformation for the people of Indonesia seemed to have taken place earlier than predicted. In mid-March 2020, the working from home (WfH) policy triggered the gaining of the momentum of digitalization in every aspect of our life: social, cultural, political and economic, as well as, in particular, the aspect of education. The phrase 'work from home' has now a broader meaning; it not only is now about learning from home but also refers to academic meetings: seminars, training courses, competence orientation sessions that are virtually organized. In fact, there was a discourse about encouraging civil servants to work at home. Plans had been evaluated by the Indonesian Ministry for Productive Management of State Apparatuses (Kemenpan-RB) and Bureaucratic Reform and State Civil Service Agency (BKN) Today, working from home for civil servants is no longer a discourse. The way it is applied, however, has nothing to do with the said discourse; rather, it is more about necessity due to the Covid-19 pandemic. ${ }^{1}$

Health and safety protocols are taken into account. Keeping a safe physical distance, avoiding contacts by staying at home, and staying away from crowds are a policy the government introduced in order to break the vicious chain of the disease. From an academic standpoint, along with arranging online ${ }^{2}$ lectures, it is compulsory for university instructors to improve their competence following the distance education protocol. Seminars are listed as academic events that these instructors are required to participate in, and attending online seminars serve to substitute the tasks that these teachers need to complete under the three education principles (tridharma) of highereducation institutions. A professional educator and a scientist, a college or university teacher must 'transform, develop and disseminate science, technology and art through education, research and public service' (Article 1 (14), Law No. 12 of 2012 on Higher Education). What this provision points out is that an instructor is accountable to their students as well as to the people. Another provision of the Law, Article 12 paragraphs (1), (2) and (3) details

1 Circular Letter Number 36962/MPK.A/HK/2020 of March 17, 2020, of the Minister of Education and Culture on Online Learning and Working from Home for Mitigating the Spread of the Corona Virus Disease (COVID-19). As a follow-up, the Director General of Higher Education issued Circular Letter Number 262/E.E2/KM/2020 of March 23, 2020, regarding Teaching and Learning during the COVID-19 Pandemic Crisis.

2 Similarly, school/university students (the learners group) are already familiar with the term 'Learning at/from Home' (LfH). what a faculty member has to do, and states that the development of academic culture has to evolve while maintaining social interaction, i.e. "the search for scientific truths, exploitation and/or cultivation of science and technology, and development of highereducation institutions as a scientific body." (Article 12 $(4))^{3}$

\section{METHOD}

This study focuses on how the lecturers viewed this concept, how they fostered social interactions, and how they carried out one of their duties under the principles of the Teachers' Tridharma when they were engaged in online seminars, commonly known as webbased seminars ${ }^{4}$. It applies the descriptive qualitative approach to identifying how they understand the aspect of social interaction. Points discussed included the brief survey's analysis of the benefits of the webinar technology for instructors in an emergency situation.

This study uses a descriptive qualitative approach to identify how the understanding of lecturers related to aspects of social interaction. The method used in this study is a survey analysis of the benefits of webinar technology for instructors in emergencies. Survey research asks several respondents about their beliefs, opinions, characteristics, and behaviors that have occurred or are currently occurring (Grove, 2010). This survey uses a questionnaire consisting of indicators of the extent to which lecturers consider attending a webinar as a must, taking into account the motivational aspects, challenges, and benefits of attending. Respondents are lecturers of state/private universities/universities as many as 622 people.

\section{RESULT AND DISCUSSION}

The effects of the Covid-19 pandemic have forced us to change the ways we interact in a number of our daily routines, in particular those that are related to education. We are directed to gradually shift from doing activities that used to be solely face-toface (offline) to working online, either synchronously or asynchronously. These are actually not new to us. We have e-gov, e-commerce, e-banking, e-shopping, e-learning and many other things we frequently get our hands on. However, those are just trends, comfortability, to support us in our daily life, and we

3 Section 1, Article 1 General Provision No. 1, Government Regulation No. 37 regarding College/University Lecturers.

4 A webinar is an online meeting or presentation that is administered real-time through the Internet. We can say that a webinar is a seminar that runs online or a website online seminar. Downloaded on July 6, 2020, from https://www. jagoanhosting.com/blog/apa-itu-webinar website with the following link http:gg.gg/k37bm 
feel no pressure to use them. The pandemic has caused a change in the comfort that comes with doing things offline, e.g. shaking hands, giving a pat on the back as a way to cheer someone up. Now, we have to do them virtually and online.

As online routines have started to gain traction, the time has come for the Indonesian Ministry for Productive Management of State Apparatuses to turn the discourse into a solid policy on requiring a prescribed number of state civil apparatuses tasked with certain jobs to work from home. In the sector of education, online learning is nothing new; it is a certainty. Before the pandemic, the Ministry of Education and Culture encouraged the application of online learning, but it had to do with justice: providing equal access to education, for everyone. At this time of crisis, online learning is no longer a matter of justice; it is required for the sake of health and safety for the administering of learning and teaching. What used to be going online 'when necessary' is now going online 'by necessity', with all the accompanying pros and cons. Circumstances can make us 'unexpectedly online', 'unexpectedly webinar', 'unexpectedly virtual', or --as Eko Indrajit calls it-- 'unexpectedly distance education'. This narrative shows us something phenomenal. Although it was expected, doing everything online is no longer an option or an alternative; it is doing everything necessary by necessity.

The use of information and communication technology, according to Katz dan Macklin-Smith $(2007,2013)^{6}$ should inevitably be complemented by technical capabilities and the preparedness to adopt such technology and the ability to adapt to it, what many refer to as ICT Literacy or digital literacy? ${ }^{7}$. ICT Literacy is the ability to access, manage, integrate, evaluate and generate information. ${ }^{8}$ This ability, as Khlaisang \& Koraneekij (2019) stated ${ }^{9}$, is the most

5 Katz \& Macklin, 2006, Information and Communication Technology (ICT) Literacy: Integration and Assessment in Higher Education, accessed from online source 17062021 https://www.researchgate.net/publication/311534921 Information_and_Communication_Technology_ICT Literacy_Integration_and_Assessment_in_Higher_Education

6 Information and communication technology (ICT) literacy: Integration and assessment in higher education (2007), Journal of Systemics, Cybernetics and Informatics, accessed at http:// www.iiisci.org/Journal/SCI/Abstract.asp?var=\&id=P890541

7 Belawati Tian, 2020, Pembelajaran Online (Edisi 2), Jakarta: Universitas Terbuka Press, p.45-80

8 Yani Nurhadryani1*, Halimah Tus Sa'diah1, Desta Wirnas2, Firman Ardiansyah1, Evaluating ICT (Information and Communication Technology), Soybean Farmers Literacy, Volume 5, Number 2, pages 128-133 e ISSN: 2089-6026, p ISSN: 2089-6026, downloaded on July 9, 2020 from http:// journal.ipb.ac.id/index.php/jika

9 Khlaisang \& Koraneekij, Open Online Assessment Management System Platform and Instrument to Enhance the important ability to possess in learning in the 21 st century, and a useful skill to have in our everyday life... ' which help promote other skills, including life and career skills and learning and innovation skills' (112)

This study started as a brief simple survey designed to know the extent of how lecturers find attending webinars a necessity, considering the aspects of motivation, challenges and benefits of such attendance. Respondents were state/private college/university lecturers $(\mathrm{N}=622)$. The results showed that respondents involved in webinars were predominantly lecturers under the adult millennial age group (31-40 years old), at $48.7 \%$, compared to those that were young millennials (aged below 30), at $18.2 \%$. The terms used to identify the age groups, i.e. young millennials (under 30), adult millennials (aged 31-40), generation X (41-50) and baby boomers (51 and over), were used by Kompas ${ }^{10}$ who classified generations based on changes in era.

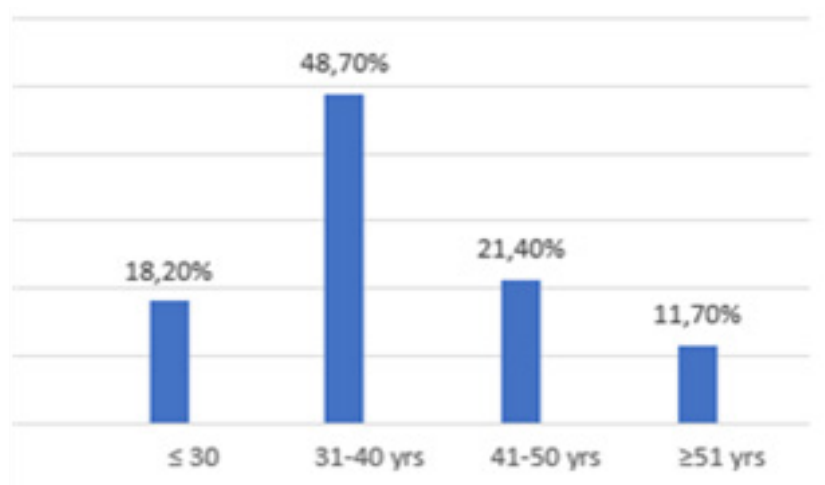

Figure 1. Webinar Attendace by Age

Actually, respondents' motivation to attend webinars before the WfH policy was in place was already high: $57.2 \%$ said they actively attended webinars. This group reported a higher number of events they were engaged in after WfH was in place, i.e. more than 5 times (43.6\%) in a month, and only a small number of respondents answered once a month (12.5\%). Regarding connectivity and the place they attended these webinars at, $69.3 \%$ specified home, and only $10.5 \%$ chose workplace. What this concludes is that it was either compliance with WfH policy was high or connectivity at home was poorer than connectivity elsewhere $(20.3 \%)$ or at the workplace (10.5\%). Ease of undisturbed access to webinars at home drove greater interest in webinars (90\%). Their attending webinars as

Information, Media, and ICT Literacy Skills of 21st Century Learners, iJET - Vol. 14, No. 7, 2019, p.111-127, accessed at https://doi.org/10.3991/ijet.v14i07.9953.

10 Kompas, July 1, 2020, results of polling by Kompas' R\&D on Scope for Improvement towards Open Indonesian Police 


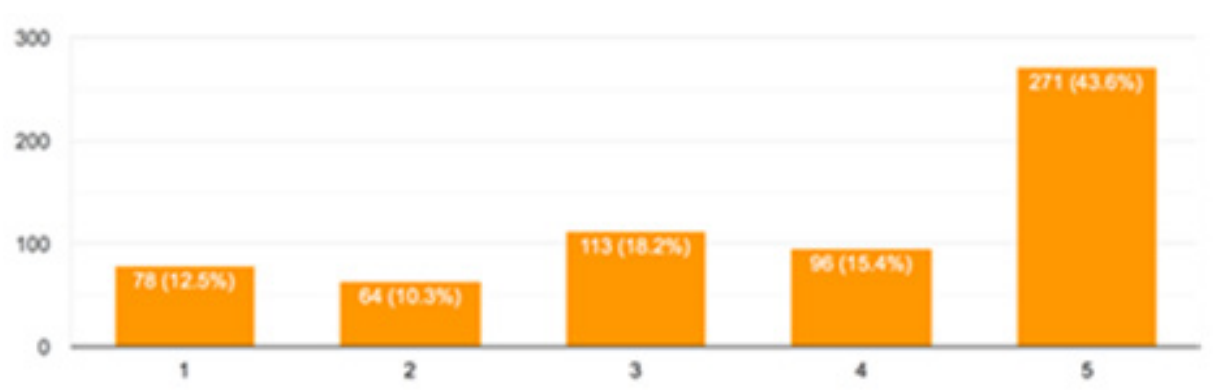

Figure 2. Frequency attending webinars in a month

registered participants proved this point. Respondents took part in a webinar not only because they found the content interesting but also because they could improve their knowledge and scientific abilities. Aside from the above academic reasons, it is without doubt that almost all webinar participants $(90 \%)$ pointed out that the award of an e-certificate was a deciding factor in their participation in seminars.

The opportunity to learn more information and improving their scientific abilities was cited as the biggest motivation for attending a webinar (84.1\%). This is a positive sign, better than earning an e-certificate as the only motivation for webinar attendance, shown by a relatively large number of respondents, at $46.3 \%$. In order to keep people who were only after e-certificates and signed in at the beginning of a webinar and then left, there were organizers who make participants to clock in at every session and give pre-tests and post-tests with questions associated with the content of the webinar. Additionally, being motivated by the material presented, as suggested by $57.2 \%$ of the respondents, was a plus considering that there were many invitations available to join various seminars with different themes for respondents to choose freely from.

Table 1. Motivation attending webinars

\begin{tabular}{lc}
\hline \multicolumn{1}{c}{ Motivation } & Total \\
\hline learn new knowledge and improve & $523(84.1 \%)$ \\
scientific abilities & \\
I was invited as a speaker & $79(12.7 \%)$ \\
the webinar content interested me & $362(58.2 \%)$ \\
speakers' expertise & $249(40 \%$ \\
e-certificate & $288(46.3 \%)$ \\
I was assigned to attend by my & $98(15.5 \%)$ \\
institution & \\
others & $33(5.3 \%)$ \\
\hline
\end{tabular}

The frequency of respondents' seminar attendance at 5 times (43.6\%) showed that there had been more opportunities to take part in seminars during the pandemic than previously available. From the research by Silvianita and Yulianto (2020), we can tell that the $56.45 \%$ of the surveyed respondents attented only 3-5 seminars over the course of one year. This confirms that as a result of the pandemic, there was a sharp increase in the number of attendance. The reason was that those seminars were available online, which made it easier for the organizers to arrange such information dissemination events and for the participants to take part in them.

As much as $90 \%$ of the respondents attended the webinars as registered participants. Those attending and participating as panelists made up only $16.6 \%$ of all attendees, which was relatively few. It indicates that only respondents who had made a name for themselves and with a high position and expertise were invited to give a presentation. Faculty members have not taken advantage of the opportunity the vast and available online seminars bring to join as speakers. What they can actually do as speakers is, in the smallest scope, e.g. in a program of study, to inform students and promote the program to the general public or to give general lectures.

Table 2. Position in webinars

\begin{tabular}{lc}
\hline \multicolumn{1}{c}{ Position } & Total \\
\hline Keynote speaker & $21(3.4 \%)$ \\
Speaker (panelist, discussant) & $82(13.2 \%)$ \\
moderator & $80(12.9 \%)$ \\
Registered participant & $560(90 \%)$ \\
Unregistered participant & $105(16.9 \%)$ \\
organizer & $86(13.8 \%)$ \\
\hline
\end{tabular}

With so many available for them to engage in, $89.2 \%$ of respondents agreed that webinars were no longer alternatives to seminars; webinars would actually serve as full-service seminars, both nationally and internationally. Having the freedom to join and fully participate in seminars would add value to the work lecturers is responsible for under the University Tridharma principles. A portion of the respondents 
opposed to the webinar alternative; this was merely for the reason of physical nature, i.e. prolonged time in front of a computer caused fatigue and boredom, and resulted in tired eyes. Psychology-wise, those who disagreed, argued that improvising in presenting materials and raising questions were not possible. Limited social interaction was also an issue.

It turned out that aside from convenience provided by online webinars, unstable network connection (79.4\%) and high cost (29.4\%) were mentioned as challenges. The government has anticipated these challenges by constructing the PALAPA RING fast internet infrastructure and devising plans on setting up 4,000 base transceiver stations (BTS $)^{11}$ even in the most remote areas the internet network all across Indonesia to ensure operational internet networks all across the archipelago. Other challenges had been recorded: digital illiteracy $(4.3 \%)$, first time using webinars (7.1\%) and non-conducive environment (11.3\%). Solutions to these should obviously include more learning, increasing the number of webinars attended and locating a place which supports the activities.

Social media are the most effective and efficient tools for disseminating information. This is true, because leads on webinars reached the participants through available platforms such as whatsapp, facebook and instagram (86.8\%). The total of $45.2 \%$ of respondents received webinar information from their friends, which was sent through personal whatsapp numbers. Sharing of information on social media is relatively cheap. Communications are responsive and redistributing them is easily possible. Webinar organizers opt for these platforms. Conventional distribution of information, e.g. sending invitations by email is still in vogue, preferred by $38.6 \%$ of the respondents, since not everyone has social media accounts.

\section{CONCLUSION}

Transformation to digitalization is a future image that is what we need today. It is the gift of necessity. Time can be arranged more effectively and efficiently in webinars, and the time spent as effectively can in fact lead to another gift, i.e. more knowledge gained. However, webinars still cannot be substitutes for the sorely-missed social interactions.

11 https://inet.detik.com/telecommunication/d-4745000/biarinternet-makin-ngebut-jokowi-4000-bts-dibangun-tahundepan
Effective attendance calls for rules to be honored before and after the webinars. Before a webinar starts, the organizer is to read out rules to be followed by attendees, and they have the right to navigate and manage all the attendees. After the end of the webinar, the organizer's duty is to remind participants to fill out the evaluation form before they can be awarded their attendance e-certificates.

\section{REFERENCES}

Belawati, Tian, 2020, Pembelajaran Online (Edisi 2), Jakarta: Universitas Terbuka Press

Groves, Robert M., (2010), Survey Methodology, Second edition of the (2004) first edition ISBN 0-47148348-6

Haryanto, agus tri, (2019). Biar Internet Makin Ngebut, Jokowi: 4.000 BTS Dibangun Tahun Depan. Detiknet, accessed from online source https://inet.detik. com/telecommunication/d-4745000/biar-internetmakin-ngebut-jokowi-4000-bts-dibangun-tahundepan

Intermedia, Beon. (2020). Apa itu webinar? Ketahui Strategi Marketing yang satu ini. Downloaded on July 6, 2020, from https://www.jagoanhosting.com/blog/ apa-itu-webinar website with the following link http:gg.gg/k37bm

Katz \& Macklin, 2006, Information and Communication Technology (ICT) Literacy: Integration and Assessment in Higher Education, accessed from online source https://www.researchgate.net/ publication/311534921_Information_and_ Communication_Technology_ICT_Literacy_ Integration_and_Assessment_in_Higher_ Education

Khlaisang \& Koraneekij. (2019) Open Online Assessment Management System Platform and Instrument to Enhance the Information, Media, and ICT Literacy Skills of 21st Century Learners, iJET. 14(7), p.111-127

Kompas. (2020). R\&D on Scope for Improvement towards Open Indonesian Police. Jakarta:Kompas

Nurhadryani,Yani, et. al, (2018) Evaluating ICT (Information and Communication Technology), Soybean Farmers Literacy. Jurnal Jika:Ilmu Komputer Agri-Informatika. 5(2) p. 128-133

Peraturan Pemerintah Nomor 37 tentang Perguruan Tinggi (2009)

Surat Edaran Menteri Pendidikan dan Kebudayaan Nomor 36962/MPK.A/HK/2020 tentang Pembelajaran Online dan Bekerja Dari Rumah dalam Rangka Mitigasi Penyebaran Corona Virus Disease (Covid-19)

Surat Edaran Dirjen Dikti Nomor 262/E.E2/KM/2020 tentang Proses Belajar Mengajar di Masa Krisis Pandemi Covid-19 